\title{
PENGARUH NON PERFORMING LOAN (NPL) DAN BUNGA PINJAMAN TERHADAP TINGKAT PROFITABILITAS BANK UMUM SWASTA NASIONAL
}

\author{
Mardi \\ Liya Faradila \\ Fakultas Ekonomi Universitas Negeri Jakarta \\ e-Mail: mardi196001@gmail.com
}

\begin{abstract}
This article aims to examine the effects caused by the non-performing loan (NPL) and interest on loan to the profitability of Indonesian private national bank in 2013. Data were obtained from Bank of Indonesia and the websites of each bank in 2013. This study used a random sampling technique which contains 55 National Private banks. The study states that there is a negative and significant impact of NPL with the profitability of the sample banks. While the interest on loan has a significant and positive effect to the profitability of the banks. Simultaneously, NPL, and interest on loan has a significant and positive effect to profitability of private national banks. Thus, the national private commercial banks should consider the level of interest on loan, which will have an impact on NPL and always pay attention to the interest on loan to achieve the level of profitability.
\end{abstract}

Keywords: interest on loans, non-performing loan (NPL), profitability.

\begin{abstract}
ABSTRAK
Artikel ini bertujuan menguji pengaruh yang disebabkan oleh Non Performing Loan (NPL) dan bunga pinjaman terhadap profitabilitas bank umum swasta nasional tahun 2013. Data yang diuji diperoleh dari Bank Indonesia dan website masing-masing bank tahun 2013.Penelitian ini menggunakan teknik random sampling sebanyak 55 Bank Umum Swasta Nasional.Hasil penelitian menyatakan bahwa terdapat pengaruh negatif dan signifikan antara NPL dengan profitabilitas bank umum swasta nasional. Sementara itu bunga pinjaman dengan profitabilitas bank umum swasta nasional berpengaruh positif signifikan. Secara simultan, NPL, bunga pinjaman dan profitabilitas bank umum swasta nasional berpengaruh positif signifikan. Dengan demikian, bank umum swasta nasional harus memperhatikan tingkat penyaluran kredit yang akan berdampak pada NPL dan memperhatikan bunga pinjaman untuk mencapai tingkat profitabilitasnya.
\end{abstract}

Kata kunci: bunga pinjaman, non performing loan (NPL), profitabilitas.

Perbankan adalah lembaga keuangan yang sangat berperan penting dalam aktivitas perdagangan internasional serta pembangunan nasional.Pada dunia ekonomi modern saat ini, masyarakat sangat membutuhkan adanya bank. Selain berperan penting dalam pembangunan perekonomian suatu negara, perbankan juga mempunyai risiko yang sangat tinggi karena tugasnya mengelola uang yang diterima dari masyarakat baik dalam bentuk pemberian kredit, pembelian suratsurat berharga serta penanaman dana lainnya. 
Sebagai salah satu pilar sektor keuangan dalam melaksanakan fungsi intermediasi dan pelayanan jasa keuangan, sektor perbankan jelas sangat memerlukan adanya sebuah distribusi risiko yang efisien. Oleh karena itu, pelaku sektor perbankan dituntut untuk mampu secara efektif mengelola risiko yang dihadapinya sehingga sektor perbankan dapat meningkatkan keuntungan atau profitabilitasnya.

Dalam memaksimalkan keuntungan suatu bank harus memperhatikan kinerja bank antara lain dengan melakukan pengukuran kemampuan hasil usaha tersebut, antara lain dengan menggunakan rasio keuangan perbankan yang meliputi rasio likuiditas, profitabilitas dan solvabilitas. Dengan menggunakan profitabilitas dapat terlihat efektivitas manajemen berdasarkan hasil pengembalian yang dihasilkan dari pinjaman dan investasi. Salah satu hal yang mempengaruhi profitabilitas adalah suku bunga kredit. Suku bunga ini akan menentukan berapa persen bunga yang akan diberikan oleh pihak bank kepada nasabanya. Selisih antara bunga yang diberikan kepada si penabung dan si peminjam akan menjadi keuntungan suatu bank. Lembaga pemeringkat internasional, Fitch Ratings menilai profitabilitas sektor perbankan Indonesia berpotensi menurun menyusul ketatnya kompetisi suku bunga kredit.Namun, prospek (outlook) secara keseluruhan masih stabil di tengah bayang-bayang krisis global yang belum mereda.Profitabilitas berpotensi turun karena margin bunga bersih (net interest margin/NIM) trennya menurun.

Salah satu faktor yang menentukan profitabilitas adalah suku bunga kredit yang berfluktuatif sehingga memberikan dampak langsung kepada nasabah dan bank itu sendiri. Suku bunga kredit yaitu persentase yang diberikan oleh bank sebagai imbalan atas pemberian kredit kepada nasabah yang nantinya akan menjadi keuntungan bagi bank. Suku bunga yang ditetapkan oleh bank harus berdasarkan dari kebijakan Bank Indonesia. Suku bunga kredit akan mempengaruhi penyaluran kredit dari suatu bank. Apabila suku bunga kredit meningkat masyarakat cenderung tidak akan meminjam uang di bank. Maka profitabilitas yang didapat oleh bank akan menurun karena rendahnya pendapatan bunga.

Semakin meningkatnya suku bunga kredit juga akan mengakibatkan adanya kredit macet, diakibatkan oleh debitur yang meminjam uang di bank kemungkinan tidak bisa membayar hutangnya. Suku bunga kredit yang tinggi akan menyebabkan masyarakat tidak bisa membayar bunga maupun pokok hutangnya sehingga menimbulkan kredit macet, hal ini meningkatkan rasio NPL (Non Performing Loan) suatu bank dan menurunkan tingkat kesehatan bank dalam hal profitabilitas.

Kredit merupakan salah satu kegiatan utama perbankan yaitu menyalurkan uang kepada orang yang membutuhkan pinjaman atau kepada orang yang defisit dananya. Kegiatan perkreditan ini dapat memberikan keuntungan bagi perbankan yaitu melalui selisih bunga yang diberikan kepada orang yang menabung di bank dengan orang yang meminjam di bank, selisih itulah yang nantinya akan menjadi keuntungan oleh bank. Dalam kegiatan kredit tentu ada yang namanya risiko. Risiko itu terjadi akibat adanya tenggang waktu, maka pengembalian kredit akan memungkinkan suatu risiko tidak tertagihnya pemberian suatu kredit atau yang biasa disebut dengan kredit macet atau kredit bermasalah. Semakin panjang suatu jangka waktu kredit, maka semakin besar risikonya. Risiko ini akan menjadi tanggungan bank sehingga akan mengurangi profitabilitas suatu bank.

Untuk mengukur risiko kreditbiasanya menggunakan NPL. NPL tinggi menggambarkan bahwa pengelolaan kredit pada bank tidak optimal yang mengakibatkan risiko kredit yang dialami oleh bank tersebut akan menjadi tinggi. Gejala peningkatan NPL hampir terjadi di semua kelompok bank kecuali Kelompok bank campuran dan bank asing. Peningkatan NPL kelompok bank persero dari Rp.146 miliar menjadi Rp.155 miliar. Kelompok bank umum swasta nasional (BUSN) devisa dari Rp.489 miliar menjadi Rp.516 miliar. Sebaliknya, NPL kelompok bank campuran malah menipis dari 
Rp.241 miliar menjadi Rp.231 miliar dan kelompok bank asing dari Rp.668 miliar menjadi Rp.663 miliar pada periode yang sama. (Anonim, 2014) Dapat dilihat terjadi peningkatan NPL yang dialami oleh perbankan Indonesia, khususnya yaitu pada kelompok bank devisa.

Van Horne (2002) menyatakan bahwa Profitability ratios are two types: Those showly profitability in relation to sales, and those showing profitability in relation to investment. Together these ratios indicates the firm's effieciency of operation. Sedangkan Brigham danWeston (2009:95), Profitability ratios, a group of ratios that show the combined effect of liquidity, asset management, and debt operating results. Selanjutnya menurut Mamduh, (2011:42) rasio ini mengukur kemampuan perusahaan menghasilkan keuntungan (profitabilitas) pada tingkat penjualan, aset, dan modal saham tertentu.

Ada tiga rasio yang sering digunakan, yaitu profit margin, return on assets (ROA) dan return on equity (ROE). Dalam penelitian ini rasio yang digunakan untuk mengukur profitabilitas adalah Return on Assets (ROA). Koch dan Scott (2003) menyebutkan bahwa ROA adalah Equals net income dividend by average total assets and, thus, measures net income per dollar of average assets owned during the period.

Profitabilitas bank dapat disintesiskan sebagai kemampuan perusahaan dalam menghasilkan laba dari kegiatan operasinya, dan sebagai penilaian atas tingkat kesehatan suatu bank. Sehat tidaknya suatu bank dapat dilihat dari rasio profitabilitasnya. Semakin besar tingkat profitabilitas suatu bank maka semakin baik efektivitas manajemen dalam menjalankan kegiatan operasionalnya. Untuk mengukur profitabilitas bank dapat menggunakan rasio Return on Asset, yaitu dengan membandingkan laba sebelum pajak dengan rata-rata total aset.

Menurut Kasmir (2011), bunga pinjaman merupakan bunga yang dibebankan kepada para peminjam (debitur) atau harga jual yang harus dibayar oleh nasabah peminjam kepada bank. Bagi bank bunga pinjaman merupakan harga jual dan contoh harga jual adalah bunga kredit. Bunga pinjaman merupakan pendapatan yang diterima dari nasabah. Salah satu keuntungan yang diperoleh bank adalah melalui bunga pinjaman. Sedangkan menurut Muchdarsyah (2000), Bunga atas kredit adalah suatu kontra prestasi atas penyerahan uang. Dengan demikian, yang dimaksudkan bunga kredit adalah suatu jumlah ganti kerugian atau balas jasa atas penggunaan uang oleh nasabah.

Menurut Ismail (2011), bunga pinjaman atau bunga kredit merupakan harga tertentu yang harus dibayar oleh nasabah kepada bank atas pinjaman yang diperolehnya. Dengan demikian bunga pinjaman (bunga kredit) dapat disintesiskan sebagai persentase dari jumlah hutang yang telah dibayarkan sebagai jasa atas kredit atau pinjaman yang telah diberikan.Bunga pinjaman yang dipakai yaitu suku bunga kredit efektif rata-rata per tahun dapat diambil dari catatan atas laporan keuangan bank.

Menurut Timothy \& Scott (2003) mendefinisikan, Non performing loan is loans are more than 90 days past due. Sedangkan Reed \& Gill (1989) mendefinisikan NPL sebagai Problem loans are those that have not been off but are at least 90 days past due, non accruing, or renegotiated. Leon and Ericson (2007) juga menjelaskan non performing loan adalah kredit yang kategori kolektibilitasnya diluar kolektibilitas kredit lancar dan kredit dalam perhatian khusus. Dengan demikian non performing loan (NPL) dapat disintesiskan sebagai kredit bermasalah dengan kata lainsuatu keadaan dimana nasabah sudah tidak sanggup membayar sebagian atau seluruh kewajibannya kepada bank seperti yang telah diperjanjikan karena alasan tertentu. Dengan demikian mengukur non perforning loan membandingkan total kredit bermasalah dengan total kredit. 
Hipotesis 1: Pengaruh Non Performing Loan (NPL) terhadap Profitabilitas

Menurut Reed danGill (1989), This rising trend was accompanied by an increase in the reserve for loan losses. As we have learned, this reserve is designed to care for potential loan losses and is transferred from current earnings; consequently, loan losses affect bank profitability. Dendawijaya (2001) juga mengatakan bahwa implikasi bagi pihak bank sebagai akibat dari timbulnya kredit bermasalah tersebut dapat berupa hilangnya kesempatan untuk memperoleh pendapatan dari kredit yang diberikannya, sehingga mengurangi perolehan laba dan berpengaruh buruk bagi rentabilitas bank dan return on assets (ROA) mengalami penurunan.

\section{Hipotesis 2: Pengaruh Bunga Pinjaman terhadap Profitabilitas}

Kapunda dan Molosiwa (2012), berpendapat The relatively high lending rate is another contributing factor to the increasing profits. Venogopal (2007) juga berpendapat, A higher lending rate will increase the interest cost of public debt and complicate the goverment's borrowing programme thought this may increase the profit of bank.

Hipotesis 3: Pengaruh antara NPL dan bunga pinjaman terhadap profitabilitas.

Sampel penelitian adalah Bank Umum Swasta Nasional yang terdaftar di BI pada tahun pengamatan 2013 yang merupakan periode terakhir publikasi laporan keuangan perusahaan yang dijadikan sampel sebanyak 55 bank.

Operasional Profitabilitas; Rasio ini mengukur kemampuan perusahaan dalam menghasilkan laba dari kegiatan operasinya, dan sebagai penilaian atas tingkat kesehatan suatu bank.Profitabilitas bank (Y) dengan rasio yang akan digunakan oeh peneliti, yaitu:

$$
\text { ReturnOnAssets }=\frac{\text { earning before interest tax }}{\text { average total assets }}
$$

Operasional Non performing loan (NPL); Non performing loandisebut jugakredit bermasalah yaitu suatu keadaan dimana nasabah sudah tidak sanggup membayar sebagian atau seluruh kewajibannya kepada bank seperti yang telah diperjanjikan karena alasan tertentu.Rasio NPL ini dapat dirumuskan sebagai berikut:

$$
N P L=\frac{\text { total } \text { kredit bermasalah }}{\text { total } k \text { redit }}
$$

Operasional Bunga pinjaman; Bunga pinjaman adalah prosentase dari jumlah hutang yang telah dibayarkan sebagai jasa atas kredit atau pinjaman yang telah diberikan. Suku bunga yang digunakan dalam penelitian ini adalah suku bunga pinjaman.Bunga pinjaman yang dipakai adalah suku bunga kredit efektif rata-rata per tahun, yang didapat dari catatan atas laporan keuangan bank tahun 2013.

Data yang diperoleh diolah berdasarkan prinsip-prinsip statistik deskriptif, menentukkan persamaan regresi serta uji asumsi klasik. Setelah persyaratan diterima, dilakukan uji hipotesis penelitian. Uji t untuk mengetahui signifikansi nilai parameter hasil regresi. Uji koefisien determinasi $\left(R^{2}\right)$ menjelaskan hubungan antara variabel dependen dan variabel independen.

\section{HASIL DAN PEMBAHASAN}

Berdasarkan Tabel 1 dapat dijelaskan bahwa, tingkat profitabilitas bank umum swasta nasional tahun 2013 rata-rata sebesar 1,66 dengan sebaran standarnya sebesar 0,9. NPL memiliki rata-rata sebesar 1,89 dan simpangan baku sebesar 1,49. Dan tingkat suku bunga pinjaman rata-rata sebesar 13,17 dan standar penyimpangan dari rata-ratanya adalah sebesar 2,71. 
Tabel 1. Statistik Deskriptif Berdasarkan Seluruh Sampel Penelitian.

Descriptive Statistics

\begin{tabular}{lrrrrrrr}
\hline & $N$ & Minimum & Maximum & \multicolumn{1}{c}{ Sum } & \multicolumn{1}{c}{ Mean } & Std. Deviation & Variance \\
\hline Profitabilitas & 55 & 0,11 & 4,54 & 91,19 & 1,6580 & 0,91227 & 0,832 \\
NPL & 55 & 0,05 & 6,75 & 103,95 & 1,8900 & 1,48524 & 2,206 \\
Lending_rate & 55 & 9,06 & 22,75 & 724,23 & 13,1678 & 2,71538 & 7,373 \\
Valid N (listwise) & 55 & & & & & & \\
\hline
\end{tabular}

Pengujian Asumsi Klasik

a. Uji Normalitas

\begin{tabular}{llrrr}
\multicolumn{5}{c}{ One-Sample Kolmogorov-Smirnov Test } \\
\hline \multirow{2}{*}{$N$} & & Profitabilitas & \multicolumn{1}{c}{ NPL } & Lending_rate \\
\hline \multirow{2}{*}{ Normal Parametersa,b } & Mean & 1,6580 & 1,8900 & 13,1678 \\
& Std, Deviation & 0,91227 & 1,48524 & 2,71538 \\
\hline \multirow{2}{*}{ Most Extreme Differences } & Absolute & 0,116 & 0,147 & 0,143 \\
& Positive & 0,116 & 0,147 & 0,143 \\
& Negative & $-0,061$ & $-0,108$ & $-0,089$ \\
\hline Kolmogorov-Smirnov Z & & 0,859 & 1,091 & 1,059 \\
\hline Asymp. Sig. (2-tailed) & & 0,451 & 0,185 & 0,212 \\
\hline
\end{tabular}

Uji Normalitas dengan menggunakan One Sample Kolmogorov-Smirnov Test dengan tingkat signifikansi sebesar 0,05 . Tingkat signifikansi dari semua variabel menunjukkan lebih besar dari 0,05 maka disimpulkan data berdistribusi normal.

\section{b. Uji Multikolinieritas}

\begin{tabular}{|c|c|c|c|c|c|}
\hline & \multicolumn{5}{|c|}{ Coefficients $^{a}$} \\
\hline & \multirow{2}{*}{ Model } & \multirow{2}{*}{$T$} & \multirow{2}{*}{ Sig. } & \multicolumn{2}{|c|}{ Collinearity Statistics } \\
\hline & & & & Tolerance & VIF \\
\hline \multirow{3}{*}{1} & (Constant) & 1,606 & 0,114 & & \\
\hline & NPL & $-3,019$ & 0,004 & 0,997 & 1,003 \\
\hline & Lending_rate & 2,140 & 0,037 & 0,997 & 1,003 \\
\hline
\end{tabular}

Disimpulkan bahwa masing-masing variabel memilki nilai VIF; NPL dan bunga pinjaman 1,003 (VIF < 10) untuk semua variabel independen dan nilai tolerance untuk semua variabel independen yaitu NPL dan bunga pinjamansebesar 0,997 >0,10 sehingga tidak ada persoalan multikolinieritas yang berarti diantara variabel-variabel independen.

\section{c. Uji Heteroskedastisitas}

Pada Scatter Plot di bawah ini menujukkan pola tertentu, misalnya pola menaik ke kanan atas, atau menurun dari kiri atas, atau pola tertentu lainnya dan titik-titik menyebar di atas dan di bawah angka 0 pada sumbu $Y$. Hal ini menunjukkan bahwa model regresi bebas dari heteroskedastisitas. 


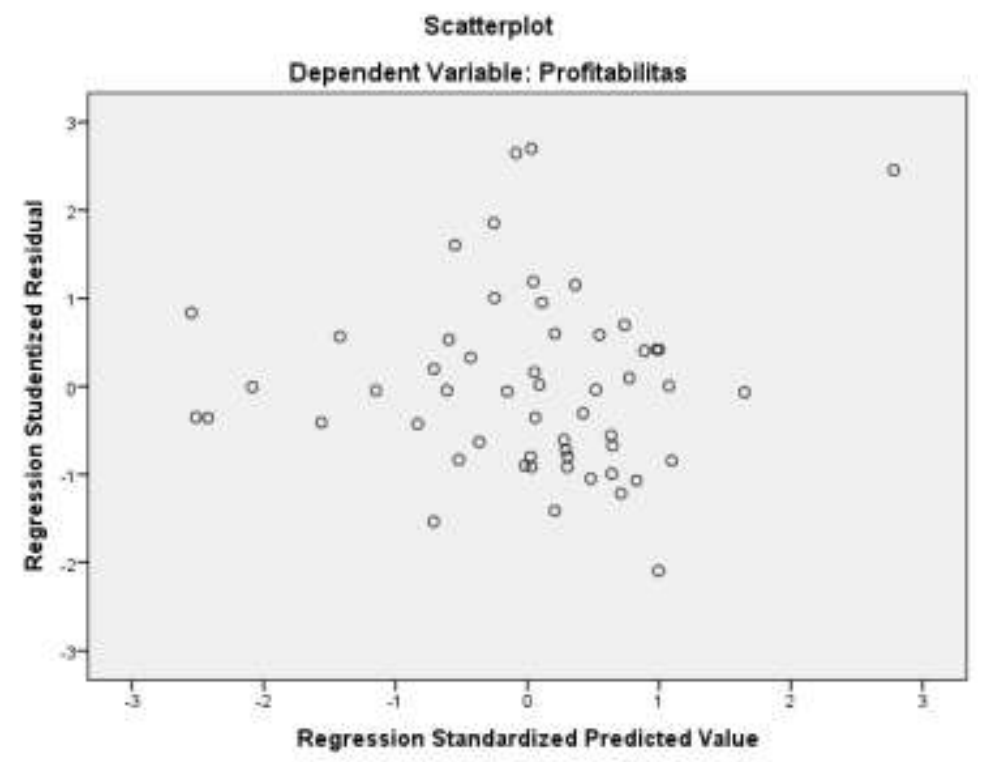

\section{d. Uji Autokorelasi}

\section{Model Summaryb}

\begin{tabular}{cccccc}
\hline Model & $R$ & $R$ Square & $\begin{array}{l}\text { Adjusted } R \\
\text { Square }\end{array}$ & $\begin{array}{l}\text { Std. Error of Durbin-Watson } \\
\text { the Estimate }\end{array}$ \\
\hline 1 & $0,448^{\mathrm{a}}$ & 0,201 & 0,170 & 0,83117 & 1,747 \\
\hline
\end{tabular}

a. Predictors: (Constant), Lending_rate, NPL

b. Dependent Variable: Profitabilitas

Pada hasil tabel di atas diketahui $\mathrm{DW}=1,747, \mathrm{DU}=1,641$. Data dalam penelitian ini menyatakan DW terletak diantara dU dan (4-DU) yaitu 1,641 <1,747 <2,359 maka data tersebut bebas dari autokorelasi.

\section{Pengujian Hipotesis}

a. Uji Koefisien Korelasi Ganda

Berdasarkan tabel di bawah angka $\mathrm{R}$ sebesar 0,448. Hal ini menunjukkan terdapat pengaruhantara NPL dan bunga pinjamanterhadap profitabilitas.

\section{Model Summaryb}

\begin{tabular}{cccc}
\hline Model & $R$ & $R$ Square & $\begin{array}{c}\text { Adjusted } R \\
\text { Square }\end{array}$ \\
\hline 1 & $0,448^{\mathrm{a}}$ & 0,201 & 0,170 \\
\hline
\end{tabular}

a. Predictors: (Constant), Lending_rate, NPL

b. Dependent Variable: Profitabilitas 


\section{b. Uji Koefisien Korelasi Simultan (Uji-F)}

Hasil uji ANOVA antara NPL dan bunga pinjamanterhadap profitabilitas menunjukkan bahwa $F_{\text {hitung }}>F_{\text {tabel }}$ atau6,526 $>3,175$ maka disimpulkan terdapat pengaruh secara simultan (bersama-sama) antara NPL dan bunga pinjamanterhadap profitabilitas.

\section{ANOVA $^{a}$}

\begin{tabular}{clcc}
\hline Model & & $F$ & Sig. \\
\hline 1 & $\begin{array}{l}\text { Regression } \\
\text { Residual } \\
\text { Total }\end{array}$ & 6,526 & $0,003^{\mathrm{b}}$ \\
& & \\
& & \\
\hline
\end{tabular}

Dependent Variable: Profitabilitas

Predictors: (Constant), Lending_rate, NPL

\section{c. Uji Koefisien Korelasi Parsial (Uji-T)}

Coefficientsa

\begin{tabular}{llrrrr}
\hline Model & \multicolumn{2}{c}{$\begin{array}{c}\text { Unstandardized } \\
\text { Coefficients }\end{array}$} & $t$ & Sig. \\
\cline { 3 - 4 } & & \multicolumn{1}{c}{$B$} & \multicolumn{1}{c}{ Std. Error } & & \\
\hline \multirow{4}{*}{1} & (Constant) & 0,918 & 0,572 & 1,606 & 0,114 \\
& NPL & $-0,230$ & 0,076 & $-3,019$ & 0,004 \\
& Lending_rate & 0,089 & 0,042 & 2,140 & 0,037 \\
\hline
\end{tabular}

Dependent Variable: Profitabilitas

Hipotesis pertama menyatakan NPL berpengaruh terhadap profitabilitas. Hasil perhitungan

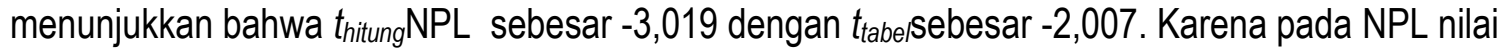
$T_{\text {hitung }}<T_{\text {tabel }}$ yaitu $-3,019<-2,007$ dan bertanda negatif serta nilai signifikansi variabel NPL 0,004 < 0,05 maka $\mathrm{H}_{0}$ ditolak, sehingga dapat disimpulkan bahwa variabel NPL berpengaruh negatif dan signifikan terhadap profitabilitas. Berdasarkan hasil tersebut disimpulkan bahwa hipotesis pertama yang menyatakan NPL berpengaruh terhadap profitabilitas terbukti, sehingga hipotesis pertama diterima.

Hipotesis kedua menyatakan bahwa bunga pinjaman berpengaruh terhadap profitabilitas. Hasil perhitungan menunjukkan bahwa $t_{\text {hitung }}$ bunga pinjaman sebesar 2,140 dengan $t_{\text {tabel }}$ sebesar 2,007 . Karena pada bunga pinjaman $t_{\text {hitung }}>t_{\text {tabel }}$ yaitu 2,140 $>2,007$ dan bertanda positif serta nilai signifikansi variabel bunga pinjaman $0,037<0,05$ maka $\mathrm{H}_{0}$ ditolak, sehingga dapat disimpulkan bahwa bunga pinjaman berpengaruh positif signifikan terhadap profitabilitas. Berdasarkan hasil tersebut disimpulkan bahwa hipotesis kedua yang menyatakan bunga pinjaman berpengaruh terhadap Profitabilitas terbukti, sehingga hipotesis kedua diterima.

\section{d. Uji Koefisien Determinasi}

\section{Model Summaryb}

\begin{tabular}{cccc} 
Model & $R$ & $R$ Square & $\begin{array}{c}\text { Adjusted } R \\
\text { Square }\end{array}$ \\
\hline 1 & $0,448^{\mathrm{a}}$ & 0,201 & 0,170 \\
\hline
\end{tabular}

a. Predictors: (Constant), Lending_rate, NPL

b. Dependent Variable: Profitabilitas 
Hasil dari koefisien determinasi dapat dinyatakan bahwa R2 adalah 0,201 atau 20,1\%. Hal ini menunjukkan bahwa presentase sumbangan pengaruh variabel independen (NPLdan Bunga Pinjaman) terhadap variabel dependen (profitabilitas) sebesar $20,1 \%$ atau variasi variabel independen yang digunakan dalam model (NPL dan bunga pinjaman) mampu menjelaskan sebesar $20,1 \%$ variasi variabel profitabilitas.

\section{Pengaruh Non Performing Loan terhadap Profitabilitas}

Dari hasil penelitian menunjukkan bahwa terdapat pengaruh negatif antara NPL dan profitabilitas (ROA). Hasil penelitian ini mendukung pendapat Dendawijaya (2001) juga mengatakan bahwa implikasi bagi pihak bank sebagai akibat dari timbulnya kredit bermasalah tersebut dapat berupa hilangnya kesempatan untuk memperoleh income (pendapatan) dari kredit yang diberikannya, sehingga mengurangi perolehan laba dan berpengaruh buruk bagi rentabilitas bank dan return on assets (ROA) mengalami penurunan.

Hasil pengujian ini juga mendukung penelitian sebelumnya oleh Eng (2013) hasil penelitian ini menunjukkan koefisien regressi NPL sebesar -0,293, dapat diartikan bahwa setiap kenaikan NPL sebesar $1 \%$ akan menurunkan ROAsebesar $0,293 \%$, dengan asumsi faktor lainnya yang dianggap konstan. Sehingga, hubungan antara NPL dan profitabilitas adalah negatif dan memiliki pengaruh signifikan.

\section{Pengaruh Bunga Pinjaman terhadap Profitabilitas}

Hasil pengujian ini juga menunjukkan bahwa terdapat pengaruh antara bunga pinjaman dan profitabilitas. Hasil penelitian ini sejalan dengan pendapat yang diungkapkan oleh Venugopal (2007) yaitu, $A$ higher lending rate will increase the interest cost of public debt and complicate the goverment's borrowing programme thought this may increase the profit of bank. Dan mendukung penelitian sebelumnya yang dilakukan oleh Kapunda dan Molosiwa (2012) hasil pengujian menunjukkan nilai regresi variabel bunga pinjaman sebesar 0,71. Ini berarti jika bunga pinjaman meningkat sebesar 1 persen maka akan meningkatkan profitability sebesar 7 persen. Hasil penelitian ini mendukung hasil penelitian yang dilakukan oleh peneliti karena nilai regresi yang dihasilkan sama yaitu bernilai posistif.

\section{Pengaruh NPL dan bunga pinjamanterhadap profitabilitas}

Berdasarkan hasil perhitungan maka, secara simultan atau bersama-sama variabel NPL dan bunga pinjaman berpengaruh secara signifikan terhadap variabel profitabilitas. Besaran pengaruhnya sebesar $20,1 \%$ atau variasi variabel independen yang digunakan dalam model,NPL dan bunga pinjaman mampu menjelaskan sebesar $20,1 \%$ variasi variabel profitabilitas.

Hasil penelitian juga menerima hipotesis ketiga yaitu terdapat pengaruh NPL dan bunga pinjaman terhadap profitabilitas yang diperkuat oleh pendapat Augustinus (2007), Suku bunga dana yang tinggi sebagai akibat dari tight bias oleh BI dengan mematok BI rate pada kisaran double digit sementara suku bunga kredit sangat sulit dinaikkan mengingat dampaknya yang sangat luar biasa kepada penurunan kualitas kredit, telah menjadikan selisih antara pendapatan bunga dengan biaya bunga menjadi mengecil sehingga mengakibatkan penurunan profitabilitas.

Hasil pengujian ini juga mendukung penelitian sebelumnya dilakukan oleh Anggreni (2014) hasil pengujiannilai regresi sebesar -0,402 menyimpulkan variabel NPL berpengaruh negatif pada profitabilitas. Hasil pengujian menunjukkan nilai regresi sebesar $-0,423$ menunjukkan variabel suku bunga kredit berpengaruh negatif pada profitabilitas. Temuan ini menunjukkan peningkatan suku 
bunga kredit akan menyebabkan penurunan profitabilitas. Hasil penelitian suku bunga kredit yang dilakukan oleh Anggreni (2014) bertolak belakang dengan hasil penelitian yang dilakukan oleh peneliti, karena nilai regresi yang dihasilkan bernilai negatif sedangkan nilai regresi yang dihasilkan oleh peneliti sendiri bernilai positif. Hal ini terjadi karena perbedaan populasi yang diteliti, peneliti menggunakan Bank Umum Swasta Nasional sedangkan penelitian sebelumnya menggunakan Bank Umum Milik Negara sebagai populasi. Selain itu perbedaan periode pengamatan juga yang mempengaruhi hasil dari penelitian ini.

\section{PENUTUP}

Jika NPL naik, maka profitabilitas akan mengalami penurunan dan sebaliknya. Hal ini terjadi karena bank kehilangan kesempatan untuk memperoleh pendapatan jika tingkat pembiayaan bermasalah meningkat sehingga berakibat buruk terhadap profitabilitas dalam hal ini yaitu ROA.Ketika bunga pinjaman meningkat maka profitabilitas akan meningkat pula dan sebaliknya. Hubungan positif signifikan ini terjadi karena jika bank meningkatkan porsi bunga pinjamannya otomatis akan meningkatkan income yang akan didapatkan oleh bank tersebut sehingga profitabilitas dalam hal ini adalah ROA akan meningkat.

Penurunan dan kenaikan NPL dan bunga pinjaman berpengaruh terhadap profitabilitas bank umum swasta nasional. Ketika non performing loan mengalami penurunan kemudian akan mempengaruhi profitabilitas yang cenderung meningkat. Pada saat yang sama ketika bunga pinjaman mengalami penurunan maka profitabilitas mengalami penurunan. Artinya bank umum swasta nasional harus memperhatikan tingkat penyaluran kredit yang akan berdampak pada NPL dan memperhatikan bunga pinjaman untuk mencapai tingkat profitabilitasnya.

Kenaikan NPL akan menurunkan profitabilitas bank umum swasta nasional. Transaksi kredit yang dilakukan oleh bank umum swasta nasional perlu diberlakukan pengawasan yang lebih ketat agar tidak diperoleh non performing loan yang lebih besar. Kenaikan bunga pinjaman biasanya dilakukan sebagai akibat adanya kebijakan BI rate yang dilakukan oleh Bank Indonesia. Kenaikan BI rate akan menyebabkan naiknya bunga pinjaman. Oleh karena itu pihak bank harus berhati-hati dan menetapkan langkah-langkah yang tepat dalam menaikkan suku bunga pinjaman. Diharapkan setiap bank senantiasa menjaga, mengawasi dan mengontrol setiap kredit yang disalurkan, sehingga risiko kredit bermasalah dalam bank dapat diminimalisir. Selain itu, pihak bank diharapkkan bisa mengatur dengan baik jumlah dana yang akan disalurkan untuk kredit, sehingga jumlah kredit yang disalurkan tidak melebihi jumlah dana pihak ketiga.

\section{REFERENSI}

Anggreini, Made Ria. (2014). Pengaruh dana pihak ketiga, kecukupan modal, risiko kredit dan suku bunga kredit pada profitabilitas. E-Jurnal Akuntansi, vol 9.1 hal. 27-38. Universitas Udayana.

Anonim. (2013). BI Rate naik, profitabilitas bank terancam melambat. Di download dari http://finansial.bisnis.com/read/20130903/90/160422/bi-rate-naik-profitabilitas-bankterancam-melambat.

Anonim. (2014). Profitabilitas perbankan bisa turun. Di download dari http://www.beritasatu.com/ ekonomi/37269-fitch-profitabilitas-perbankan-bisa-turun.html.

Brigham, Eugene F., \& Joel F. Weston. (2009). Fundamentals of financial management. Nelson Education, Canada.

Dendawijaya, Lukman. (2001). Manajemen perbankan. Ghalia Indonesia, Jakarta. 
Eng, T.Sau. (2013). Pengaruh NIM, BOPO, LDR, NPL \& CAR Terhadap ROA Bank Internasional Dan Bank Nasional Go PublicPeriode 2007 - 2011. Jurnal dinamika manajemen, vol. 1 no.3 Juli .

Ghozali, Imam. (2011). Aplikasi Analisis Multivariate Dengan Program IBM SPSS 19. Semarang: Badan Penerbit Universitas Diponegoro.

Hanafi, Mamduh M. (2011). Manajemen keuangan, BPFE, Yogyakarta.

Ismail, T, (2011). Manajemen perbankan dari teori menuju aplikasi. Kencana.

Kapunda \& Molosiwa. (2012). Economics performance of commercial banks in bostwana, International journal of economics and business studies, vol. 2(1): Spring 2012, India.

Kasmir. (2011). Dasar-dasar perbankan. PT. Raja Grafindo Persada, Jakarta.

Leon, Boy \& Sonny Ericson. (2007). Manajemen aktiva passiva bank non devisa. Grasindo, Jakarta. Muchdarsyah, Sinungan. (2000). Manajemen Dana Bank, Bumi Aksara, Jakarta.

Reed, Edward K \& Edward K Gill. (1989). Commercial banking. Prentice hall International, London. Van Horne, James C. (2002). Financial management and policy. Prentice Hall International Inc, USA. Venogopal. (2007). Fiscal And Monetary Reforms In India. I. K. International publishing house, India. W.Koch, Timothy \& S. scott Mac Donald. (2003). Bank management. Thomson Learning, United States of America. 